\title{
Rethinking Exceptionalism in an Age of Plague: An Introduction
}

Our current predicament-in which the entire human species is confronted by the existential crises of climate change, on the one hand, and a seemingly interminable pandemic, on the other-might seem, if nothing else, like an appropriate moment to relinquish any pretense to exceptionalism. How could anyone possibly cling to the fancy of exemption, to what María del Pilar Blanco describes in her article in the following pages as the "dream of untouchability," in the face of threats that make no distinction among cultures or creeds? And yet, as a number of the contributors to this issue's "Rethinking Exceptionalism" cluster point out, one of the most distressing paradoxes of this "age of disruption" (Torpey) is the resilience, even the efflorescence, of exceptionalist thought. If both climate change and the COVID-19 pandemic are catastrophes produced and exacerbated by the very global interconnectedness of the contemporary world, the desperate, haphazard, and woefully uncoordinated responses of national governments and international health organizations have too often devolved into or been co-opted by an impulse to monopolize or, worse, monetize resources in the interest of the privileged few.

Last year, working under the leadership of my predecessor, Wai Chee Dimock, the PMLA Editorial Board decided to put together the Theories and Methodologies section "Rethinking Exceptionalism" in an attempt to derive an opportunity for critical reflection from a confounding set of circumstances. The novelty of the collective undertaking here is signaled in the title, which is deliberately not circumscribed by the project of rethinking American exceptionalism in particular. Without ignoring the prominence of the United States as a case study, the essays gathered here attempt as a group to rethink exceptionalism at a broader and less settled scale of comparative analysis.

There is an enormous and robust body of interdisciplinary scholarship on the topic of American exceptionalism at the intersections of fields including history, political science, sociology, international affairs, public policy, and law. As a point of entry into this sprawling

(C) 2022 The Author(s). Published by Cambridge University Press on behalf of the Modern Language Association of America 
interdisciplinary conversation, one might first cite the significant bibliography of work tracing the complex lineage of American exceptionalism as a discourse with roots in the republican and millennial traditions of the early United States, revised and expanded into "an explanatory locomotive of profound, enduring historical difference" in the Cold War era (Rodgers 21; see, e.g., Bell; Ceaser; Deneen; Hughes; Kammen; Madsen; McDougall; Pease, New American Exceptionalism and "Re-thinking"; Ramrattan and Szenberg; Tyrrell, American Exceptionalism and "American Exceptionalism"). If there are withering critiques of the delusional jingoism of the tendency to view the United States as exceptional (including Fatton; Hodgson; Ignatieff; Sachs; Walt), there is also a long-standing tradition of qualified apology for or even celebration of the claim that the unique qualities of the United States make it an exemplary nation-state and even bestow on it a tutelary mission to spread and enforce the ideals of liberal democracy throughout the globe (Huntington; Koh; Lipset; Restad; Shafer). In addition, as Elizabeth Duquette has pointed out, since 9/11 debates about exceptionalism have been transformed by the emergence of a discussion in European political theory (especially in the work of Giorgio Agamben and in renewed attention to the writings of Carl Schmitt) that poses the question of the fundamental role of the exception in the establishment and maintenance of political sovereignty (Duquette 476-79; see also Huysmans; De Boever).

Whether in ongoing discussions of American exceptionalism or in contemporary theories of sovereignty, the focus is on what Agamben calls the "political realm" (Homo Sacer 6) and at the scale of the nation-state. As Agamben puts it, politics "appears as the truly fundamental structure of Western metaphysics insofar as it occupies the threshold on which the relation between the living being and the logos is realized." Revising Schmitt's well-known formulation of the political, Agamben continues, "[T]he fundamental categorical pair of Western politics is not that of friend/enemy but that of bare life/political existence, zoē/bios, exclusion/inclusion" (8). In contrast, the aim of the cluster of articles in this issue is to rethink exceptionalism as a discourse that inherently exceeds the political realm and that operates on multiple registers. As Galen Brokaw suggests in his piece, if exceptionalism is "most often associated with the political posturing of certain nation-states," still it can be taken to refer "to any discourse that exaggerates the significance of peculiarities in order to set one group apart from, and above, others."

This point could even be taken further, since exceptionalism is not necessarily only a matter of the characteristics of a given population segment. Instead one might observe in recent scholarship something of a proliferation of analyses of exceptionalisms of various sorts, in which the term is used to identify historical phenomena, social institutions, and analytical categories as seemingly disparate as "disaster exceptionalism," "music exceptionalism," "creole exceptionalism," "climate exceptionalism," "aesthetic exceptionalism," "diaspora exceptionalism," "Internet exceptionalism," "collegiate exceptionalism," and "human exceptionalism" (see, respectively, Luft; Beaster-Jones; Degraff; Nagle; De Boever; Jean-Charles; Stokes; Greenstein; Oakley; Kirby). In modeling this expanded purview by including the contributions by Deborah Jenson (on "cognitive exceptionalism") and Brokaw (on "glottographic exceptionalism") in addition to a number of articles on national exceptionalisms in a more conventional sense, this special cluster has been organized to make the case that we must learn to think exceptionalism across conceptual registers. Indeed, the grouping is meant to imply that we are missing something crucial in the mechanics of exceptionalist thought when we fail to notice its profligacy-its rampant application in apparently incommensurate domains. To come to terms with the ideological function of American exceptionalism or l'exception française, in other words, we must not only be able to toggle between them, recognizing, as Christy Pichichero argues in her article in this cluster, that "French and American exceptionalisms have been declaredly coconstitutive" throughout their history. We must also be able to consider the constitutive interplay between national exceptionalism of any stripe and, say, disaster exceptionalism or human 
exceptionalism (as María del Pilar Blanco, Anne Anlin Cheng, and Deborah Jenson could be said to suggest in their respective pieces).

This is to say that the "Rethinking Exceptionalism" pieces ask to be read in the old-fashioned way: in tandem as a "special section," a collective grouping that only assumes its full implications in the ways the individual pieces speak to or resonate with one another. Some of the articles do require us to shift among scales even as we read them; this effect is perhaps most notable in Seeta Chaganti's stunningly original contribution. She suggests that the institutional history of policing and incarceration in the United States-by any standard, a unique if perhaps not exactly "exemplary" national characteristicdepends on a specific sense of time and causality, and turns to Boethius to excavate a premodern abolitionist critique of the "inevitability" of the carceral. Her article asks us not only to read across periods but also to think across putative disciplinary boundaries between theology and politics, as she puts The Consolation of Philosophy into conversation with Policing the Crisis, the seminal 1978 study of policing and authoritarian populism in the British state's discursive production of the so-called crisis of "mugging" in the United Kingdom. Nevertheless, in the cluster overall the case is made in the ways we are forced to rethink exceptionalism as it is resituated in the sometimes jarring leaps in context from one article to the next.

It is worth briefly revisiting the vast scholarship on American exceptionalism to glean some of the characteristics of exceptionalist thought in general. Duquette offers a succinct definition of the phenomenon:

American exceptionalism is a set of loosely related propositions that collectively assert the unique nature of the United States, its exemption from the historical forces that buffet the rest of the world. Gesturing to what the United States lacks-most notably, a feudal past and a robust socialist or Marxist traditionexceptionalist ideology maintains that the problems and paradigms that exist elsewhere are not germane to the United States. It has justified territorial expansion, authorized intervention in foreign wars and the domestic affairs of sovereign nations, and vigorously, sometimes aggressively, promoted free market capitalism.

Exceptionalist discourse is less a set of coherent tenets than what Donald Pease calls a "complex assemblage of . . . assumptions" that can be, and in fact must be, reformulated and revised over time (New American Exceptionalism 7). Duquette calls American exceptionalism the "organizing myth" of the national self-understanding (473), while Pease describes it as a "state of fantasy," not in the sense of a delusion or a mystification that one might be able to puncture or dispel, but instead as the "dominant structure of desire out of which U.S. citizens [have] imagined their national identity" (New American Exceptionalism 1). As a state of fantasy, the discourse of American exceptionalism can be and often is self-contradictory, even extravagantly so, perhaps most obviously in the respect that it "allows the United States to position itself simultaneously as a model for other nations while positing that it is unlike them in its fundamental values and structures" (Duquette 473). As "engines of national self-consciousness" (Rodgers 22), exceptionalist discourses are structured as performatives: as Nikhil Pal Singh has stressed, they "seek to produce what they purport to describe. They are civic ideologies, normative and pedagogical statements that attempt to create or reinforce a particular narrative of national identity" (18-19). For this reason they are never fixed in perpetuity, but must be continually updated in response to the transformations of the geopolitical landscape (see Pease, "Re-thinking" 20). As Singh writes, the exceptionalist "story of nationhood must be told over and over, because there is nothing natural about the nation or the fashioning of its predominant civic identities" (19).

Exceptionalist thought is unavoidably "relational," as Abdoulaye Gueye puts it (224): it posits one entity or polity as unique, exemplary, and exempt in contrast to some outside or other. According to Daniel Rodgers,

[a]n exceptionalist nation is not simply different from all others. An exception is a deviation from a 
rule. Like difference arguments, exceptionalist claims depend on an imagined "elsewhere." But what makes them so powerful is that they bundle the world's immense variety into general historical tendencies that govern everywhere except at home. Exceptionalist arguments universalize history so that the exceptionalist nation's peculiarities appear to stand out against the tendencies of the world. They create a "here" and an "elsewhere" in which, in an important sense, history itself runs by different dynamics.

This universalizing drive of exceptionalist thought is key: it is precisely because of the postulation that the United States is somehow immune from or untainted by the pitfalls of identity everywhere else - a country founded on an "egalitarian tradition of civic nationalism" distinguishing it from "nationstates with ethno-racial conceptions of the polity, or ones in which national belonging is defined by kinship, primordial attachments, and a metaphorics of blood" (Singh 18) - that it can be said to represent a "universalism beyond race" (33) and a template for liberal democracy around the world. As Singh points out with an appropriately paradoxical formulation, the self-professed "exceptional universalism" (19) of the United States was a driving force in the spread of American influence globally across the twentieth century:

The emergence of U.S. internationalism as the dominant internationalism after World War II brought with it a renewal of a core nationalist ideology: the notion of America as a republic at once unique and universal. What was most distinctive about this idea, as it was transferred from its continental and hemispheric dominion to a global scale, was the insistence that the U.S. capacity to mediate the general interests of humanity (in other words, to civilize) derived from America's distinctiveness as a power amicably divorced from old world intrigues of empire and hierarchies of blood and rank. Rather than being antithetical to U.S. nationalism (or to U.S. national interests), America's global reach was represented as an outgrowth of the universalizing force of U.S. national ideals-America, to paraphrase Benjamin Franklin['s] famous words, as the cause of all mankind.

(136-37)
Or, as Patrick Deneen puts it using a slightly different vocabulary, despite the internal contradictions between the main ideological currents in American exceptionalism - between the "liberal exemplarism" that might seem to signal a tendency toward isolationism, on the one hand, and the "liberal expansionism" that might seem to point to imperialist ambition, on the other-historically these two trajectories have tended to converge:

[T] he exemplarist view of America as a beacon to other nations was easily paired with, and even informed by, a necessarily expansionist mind-set oriented toward domestic liberalization. . . . It may rather be the case that American exceptionalism expressed in its liberal guise contains an inherent tendency toward expansionism, with its relatively more exemplarist international disposition eventually giving way to an expansionism that first seeks domestic dominance and then extends outward into the world stage.

Michael Denning famously observed more than three decades ago that "the notion of 'American exceptionalism' is in many ways the foundation of the 'discipline' of 'American Studies,"' which initially took as its mandate the elaboration of the national "mind" or "character" (360). Some of the contributions in the "Rethinking Exceptionalism" cluster can be described as emerging out of the critical turn to a "postexceptionalist" or "new" American studies that commenced in the early 1990s (see Pease, "Re-thinking" 19; Rodgers 32-39; Spanos 292). Thus María del Pilar Blanco examines the ways that ecological disaster "restyles US exceptionalist ideology as it steps outside the immediate homeland," looking at the United States response to two devastating storms in Puerto Rico (Hurricane San Ciriaco in 1899 and Hurricane Maria in 2017) as a form of "resentful humanitarianism," in which the fantasy of American exceptionalism had to be redefined in the face of the plight of a population that the United States state had "incorporated for strategic gain." And Ilya Vinitsky takes us on a dizzying archival dive into the phantasmagoric history of "Shambhala," the "ultimate fake" utopia that exposes 
the fantasy structure of American exceptionalism for the myth-making projection it is.

Both Anne Anlin Cheng and Josephine Park rethink the implications of American exceptionalism from the vantage of one of its most striking perversities. As Blanco phrases it bluntly, "exceptionalism operates by taking exception." Even as the discourse of national exception emphasizes the uniqueness and privilege of the United States in contrast to an imagined "elsewhere," it simultaneously proliferates an unending series of internal exclusions: segments of the American populace that remain, in Cheng's words, "close enough to be utilitarian but not too close, incorporated but not assimilated, consumed but not digested." Étienne Balibar has argued that the practice of internal exclusion-and in particular the figure of the racial or ethnic "minority" - is a "strict correlate of the nation-form" itself ("Ambiguous Universality" 53), and in that sense a familiar element in national exceptionalism in general. ${ }^{1}$ But it takes on specific contours in American history.

Park in particular focuses on the foundations of the "model minority" myth (in other words, the ironic structure of an "Asian American exceptionalism") in the cauldron of America's imperial wars in Korea and Vietnam and, at home, in the egregious forced detention of Japanese Americans in internment camps during World War II. As both Singh and Pease have forcefully argued, these violations of the principles of liberal democracy should be understood not as isolated irregularities but as regularly repeated instances-including, among many others, the 1850 Fugitive Slave Act, the Jim Crow laws of the 1890s, the description of Puerto Rico as "foreign to the United States in a domestic sense" in the 1901 Supreme Court decision in Downes v. Bidwell (United States 341), and "Operation Wetback" in the 1950s-in which the state reiterated its authority to create exceptions to its own supposed principles. As glaringly hypocritical as they might seem, these internal exceptions "regulated US citizens' responses to historical events," Pease writes, by providing them with powerful psychosocial "structures of disavowal" ("Re-thinking" 19). According to Singh, "the denial of the historical legacies of racism and empire had long been central to American Exceptionalism. From the inception of the slaveholding republic, finessing the contradictions between the racial and imperial parameters of U.S. nationalism and its universalizing claims was one of the more refined exercises of American social thought" (137).

In helping to set the agenda for a "postexceptionalist" American studies, both Pease and Amy Kaplan called for scholarship that would not only critique what they influentially described as the "cultures of United States imperialism" from within, but also would undertake what Pease termed a "comparative study of empires" that would elucidate the "contestatory geopolitical terrain" in which various imperial discourses of exceptionalism necessarily have to operate ("Re-thinking" 24; see also Kaplan; Kaplan and Pease). In contrasting the American and French versions of exceptionalism, Pichichero's article is very much in this vein, which has emerged into an important area of comparative imperial history and cultural studies (see, e.g., Doyle; Eskildsen; Fuchs; Go 205; Lowe; Shih).

In his 2003 preface to the anniversary edition of Orientalism, Edward Said contended that the discourse of empire is exceptionalist by definition: "Every single empire in its official discourse has said that is not like all the others, that its circumstances are special, that it has a mission to enlighten, civilize, bring order and democracy, and that it uses force only as a last resort" (xvi). Ann Laura Stoler has elaborated this point in a suggestive manner, writing that "imperial states by definition operate as states of exception that vigilantly produce exceptions to their principles and exceptions to their laws. From this vantage point, the Unites States is not an aberrant empire but a quintessential one, a consummate producer of excepted populations, excepted spaces, and its own exception from international and domestic law" (57). For Stoler, all empires are

founded on gradated variations and degrees of sovereignty and disenfranchisement-on multiplex criteria for inclusions and sliding scales of basic rights. Each generated imperial conditions that required constant 
judicial and political reassessments of who was outside and who within. Each required frequent redrawing of the categories of subject and citizen, fostering elaborate nomenclatures that distinguished among "resident alien," "naturalized citizen," "national" "immigrant," or "U.S. citizen" without voting rights-as in the case of Guam. All produced scales of differentiation and affiliation that exceeded the clear division between ruler and ruled. These are enduring forms of empire, force fields of attraction and aversion, spaces of arrest and suspended time. In imperial discourse, they are framed as unique cases-but they are not exceptions to imperial formations.

In one of his most resonant formulations, Said suggested that the study of empire should be "contrapuntal":

A comparative or, better, a contrapuntal perspective is required in order to see a connection between coronation rituals in England and the Indian durbars of the late nineteenth century. That is, we must be able to think through and interpret together experiences that are discrepant, each with its particular agenda and pace of development, its own internal formations, its internal coherence and system of external relationships, all of them co-existing and interacting with others.

(Culture 32) $^{2}$

As Blanco mentions, William Spanos has adopted Said's figure to describe the recent current of American studies scholarship that has attempted to trace American exceptionalism itself "from the point of view of the disavowed victims of its representational and global practice (contrapuntally, as it were)" (Spanos 303).

Although the figure of musical counterpoint in Said's work is framed as a question of attending to the "actual experience of empire" (32) as staged between metropole and colony, one might suggest that it can also be applied to the study of comparative imperialisms and, perhaps even more intriguingly, to the study of comparative anticolonialisms. Peter Kalliney's contribution to the cluster takes the question of "Rethinking Exceptionalism" in this direction, with his provocative approach to the anticolonialism of the Afro-Asian Writers' Association. Considering the pivotal role of translation and multilingualism in Lotus, one of the great periodicals of the Global South, Kalliney contends that in its relentlessly contrapuntal form-juxtaposing contributions from different national contexts without providing the reader with an analytical thread to link them-Lotus pursued a "paradoxical platform" for rethinking exceptionalism, "promoting cultural particularity through translation and horizontal comparison."

Aside from Kalliney's consideration of the staging of anticolonial exceptionalism in the form of the literary periodical and Park's compelling close reading of Mitsuye Yamada's poem "Inside News," the contributors to the cluster have little to say about the implications of rethinking exceptionalism for the study of literature. But it is worth pausing to consider the impact of this cluster's experiment in collective heuristics for our understanding of the literary. ${ }^{3}$ I am thinking less of what we might describe as the literature of American exceptionalism in particular: there is a substantial body of scholarship on the ways the American literary tradition has been animated by the embrace or the critique of exceptionalist thought. Instead I am wondering about the possibility of suggesting literary cognates to the comparative project of rethinking exceptionalism enacted across the articles in this cluster.

One place to start might be Pease's argument that the structure of disavowal integral to American exceptionalism pivots on a question of figuration. "State fantasies do not altogether conceal the inconsistencies that they mask," he writes. "State fantasies disclose and open up irreconcilable rifts that provide the state's subjects with a space wherein they can change their relationship to what is worst about the U.S. imperial state formation and start to let go" (New American Exceptionalism 37). This possibility arises through the eruption of what Pease calls "limit figures" or (following Walter Benjamin) "dialectical images": for Pease, these are "figures that could not be included within these fantasies without bringing them to their limits" (37), in a representational crisis that functions both to "reveal the profound social antagonisms that these fantasies structurally disavowed" 4 and also to open "sites in which an alternative state of justice might emerge" (38). Writing in another age of disaster, Pease highlights the video footage of the 1991 beating of Rodney King as one such "limit figure," but such an analysis seems clearly applicable to a 
host of recent examples (the deluge of recorded killings of African American men and women at the hands of the police; the television coverage of the storming of the United States Capitol in January 2021). Without neglecting the specific role of visual culture and mass media in these examples, it would be possible to extend Pease's argument into a broader analysis of the politics of figuration in a manner that would include the literary.

If for Agamben the sovereign exception is not only a central feature of the political realm but also the "original-if concealed-nucleus of sovereign power" (6), if "Western politics first constitutes itself through an exclusion (which is simultaneously an inclusion) of bare life" (7), we might wonder with Fred Moten how to "analyze the originary power of a figure that depends on the originary violation of the normativity that guarantees that power" (40-41). Moten points out that this model of political sovereignty provides "no analytic for the unmaking-the first refusal-to which sovereign power answers, no sense whatever of something like an anoriginal fugitivity to which the rule of law responds." And so, in his words, the question remains: "To what tradition can we turn for a thought of the outside?" (41). Moten calls for the "contemplation of the history of the exception to the state of exception-the fugitive; the outlaw, the impossible domestic, the incorrigibly, promiscuously questioning maid; the one whom Cedric Robinson calls the 'internal alien,' she who disrupts the originary force of the very state that her choreographic refusal of assimilative exclusion (her ecstasy-belonging) guarantees" (42). If Black radicalism is another name for this anoriginal fugitivity, for Moten, it is also a question of aesthetics, the "autopoiesis of imagined, imagining things" (43), in a manner that resonates with Jenson's meditation in her article included here on Sylvia Wynter's figure of the "ceremony" as a "model of a nonsolipsistic, distributed, rhythmic, nonlinear, embodied autopoietic cognition" that undoes the exceptionalism of a "cerebral subject representing the consubstantiality of brain with self in Western cultures."

What would it mean to theorize an antiexceptionalist literature as privileged vehicle for the elaboration of a thought of the outside? Wouldn't it have to imply something more than a fiction that exposes the pomposity and self-sanctioned abuses of the exceptionalist mindset? I think of the astonishing opening of Bessie Head's 1974 novel A Question of Power: "It seemed almost incidental that he was African. So vast had his inner perceptions grown over the years that he preferred an identification with mankind to an identification with a particular environment. And yet, as an African, he seemed to have made one of the most perfect statements: 'I am just anyone"' (11). If in the course of the novel "the possibilities of massive suffering were being worked out" in the head of Elizabeth, the troubled South African migrant protagonist, it culminates in the abandonment of the "power"-the word the book thoroughly, dazzlingly rethinks-of exceptionalism. Or, as this lesson is summarized: "Never think along lines of I and mine. It is death" (134). It is an epiphany forged in suffering, the specific historical suffering of peoples of African descent. "Black people learnt that lesson brutally," Elizabeth muses, "because they were the living victims of the greed inspired by I and mine and to hell with you, dog" (134). But out of that particularity-signaled with that critical qualifier "And yet, as an African"there comes a universal insight: "Africa had nothing, and yet, tentatively, she had been introduced to one of the most complete statements for the future a people could ever make: Be ordinary" (39).

Brent Hayes Edwards

\section{NOTES}

1. Balibar writes that in the demographic consolidation of national populations in the nineteenth century, "minority" status was "considered an exceptional phenomenon. More precisely, it was a normalized exception. Nineteenth-century nationalism and nation-building politics had led to a double-edged situation. On the one hand, it was considered 'normal' that a nation-state be 'ethnically' (if not religiously) homogeneous, above all from the point of view of the official language (which had all sorts of cultural effects, since it was the language of law, politics, education, administration, etc.). On the other hand it was precisely because political entities were generally conceived as nation-states that minorities officially existed, i.e. populations were formally classified 
according to their 'national' or 'ethnic' (sometimes also religious) membership, and individuals were identified with their 'common' majoritarian or minoritarian status, in spite of all their other differences and likenesses. The very existence of minorities, together with their more or less inferior status, was a state construct, a strict correlate of the nation-form" ("Ambiguous Universality" 53). He adds crucially that "racism is not a simple excess of identity feelings or xenophobia, but more specifically linked with internal exclusion, i.e. hostility and discrimination taking place among populations which are not really separated, but belong to the same society and are culturally mixed with one another" (55). See also his important essay "Racism and Nationalism," in which he links this point to the history of European colonialism: "The heritage of colonialism is, in reality, a fluctuating combination of continued exteriorization and 'internal exclusion"” (43).

2. For considerations of counterpoint as a methodological figure in Said, see, e.g., Capitain; Chowdhry; De Groot; Lachman; Wilson. As Capitain has pointed out in his detailed analysis, there is a notable fluctuation in Said's definition of the term. In some of his work, Said seems to suggest an understanding of counterpoint as one of the main compositional procedures in the Western classical tradition and thus as an approach deeply based in diatonic harmony: "In the counterpoint of western classical music," he writes in Culture and Imperialism, "various themes play off one another, with only a provisional privilege being given to any particular one; yet in the resulting polyphony there is concert and order, an organized interplay that derives from the themes, not from a rigorous melodic or formal principle outside the work" (51). Elsewhere in the same book, however, he defines the contrapuntal in a manner that suggests it is an emblematic figure of dissonance: "this global, contrapuntal analysis should be modelled not (as earlier notions of comparative literature were) on a symphony but rather on an atonal ensemble; we must take into account all sorts of spatial or geographical and rhetorical practices-inflections, limits, constraints, intrusions, inclusions, prohibitions-all of them tending to elucidate a complex and uneven topography" (318). In the light of this second passage, Said's insistence that contrapuntal analysis means that "we must be able to think through and interpret together experiences that are discrepant" (32) seems closer to Nathaniel Mackey's definition of "discrepant engagement" as a methodological approach that foregrounds "practices that, in the interest of opening presumably closed orders of identity and signification, accent fissure, fracture, incongruity, the rickety, imperfect fit between word and world" (Mackey 19).

3. Raising the same question, Duquette notes intriguingly that "Agamben's aim is to energize readers into a new politics, one he glimpses in the example of a fictional character-Herman Melville's famous scrivener, Bartleby-where the ability to resist and reject exceptional traps created by sovereignty, power, law, and violence might become possible" (479). She is alluding to Agamben's contention that the refrain uttered by Melville's character ("I would prefer not to") represents "the strongest objection against the principle of sovereignty" (Agamben, Homo Sacer 48). See also Whyte's article on Agamben's reading of Melville, as well as Agamben's article "Bartelby; or, On Contingency."
4. In a related tone, Rodgers writes, "Because displacement and censure are so central to the exceptionalist frame, challenges to the nation imagined in its terms often cut very close to the bone. When the boundaries between rule and exception shift, the banished and exported parts of one's history threaten to return" (30).

\section{Works Cited}

Agamben, Giorgio. "Bartleby; or, On Contingency.” Potentialities: Collected Essays in Philosophy, translated by Daniel Heller-Roazen, Stanford UP, 1999, pp. 243-71.

- Homo Sacer: Sovereign Power and Bare Life. Translated by Daniel Heller-Roazen, Stanford UP, 1999.

Balibar, Étienne. “Ambiguous Universality.” Differences, vol. 7, no. 1,1995 , pp. $48-74$.

. "Racism and Nationalism." Race, Nation, Class: Ambiguous Identities, edited by Balibar and Immanuel Wallerstein, translated by Chris Turner, Verso, 1991, pp. 37-67.

Beaster-Jones, Jayson. "Beyond Musical Exceptionalism: Music, Value, and Ethnomusicology.” Ethnomusicology, vol. 58, no. 2, spring-summer 2014, pp. 334-40.

Bell, Daniel. “American Exceptionalism Revisited: The Role of Civil Society.” The Public Interest, vol. 95, spring 1989, pp. $38-56$.

Capitain, Wouter. "From Counterpoint to Heterophony and Back Again: Reading Edward Said's Drafts for Culture and Imperialism." Journal of Musicological Research, vol. 40, 2020, pp. 1-22, https://doi.org/10.1080/01411896.2020.1787793.

Ceaser, James W. "The Origins and Character of American Exceptionalism." American Political Thought, vol. 1, no. 1, spring 2012, pp. 3-28.

Chowdhry, Geeta. "Edward Said and Contrapuntal Reading: Implications for Critical Interventions in International Relations.” Millennium: Journal of International Studies, vol. 36, no. 1, 2007, pp. 101-16.

De Boever, Arne. Against Aesthetic Exceptionalism. U of Minnesota P, 2019.

Degraff, Michael. "Linguists' Most Dangerous Myth: The Fallacy of Creole Exceptionalism." Language in Society, vol. 34, no. 4, 2005, pp. 533-91.

De Groot, Rokus. "Edward Said and Polyphony.” Edward Said: A Legacy of Emancipation and Representation, edited by Adel Iskandar and Hakem Rustom, U of California P, 2010, pp. 204-26.

Deneen, Patrick J. "Cities of Man on a Hill." American Political Thought, vol. 1, no. 1, spring 2012, pp. 29-52.

Denning, Michael. “The Special American Conditions': Marxism and American Studies." American Quarterly, vol. 38, no. 3, 1986, pp. 356-80.

Doyle, Laura. Inter-imperiality: Vying Empires, Gendered Labor, and the Literary Arts of Alliance. Duke UP, 2020.

Duquette, Elizabeth. "Re-thinking American Exceptionalism." Literature Compass, vol. 10, no. 6, 2013, pp. 473-82. 
Eskildsen, Robert. "Of Civilization and Savages: The Mimetic Imperialism of Japan's 1874 Expedition to Taiwan." American Historical Review, vol. 107, no. 2, 2002, pp. 288-418.

Fatton, Robert, Jr. The Guise of Exceptionalism: Unmasking the National Narratives of Haiti and the United States. Rutgers UP, 2021.

Fuchs, Barbara. Mimesis and Empire: The New World, Islam, and European Identities. Cambridge UP, 2009.

Go, Julian. "The Provinciality of American Empire: 'Liberal Exceptionalism' and U.S. Colonial Rule, 1898-1912." Comparative Studies in Society and History, vol. 49, no. 1, Jan. 2007, pp. 201-14.

Greenstein, Shane. How the Internet Became Commercial: Innovation, Privatization, and the Birth of a New Network. Princeton UP, 2015.

Gueye, Abdoulaye. "A View from the South: France in African Eyes: Universalism and Francophonie Reassessed." The End of the French Exception? Decline and Revival of the 'French Model,' edited by Tony Chafer and Emmanuel Goldin, Palgrave Macmillan, 2010, pp. 223-36.

Head, Bessie. A Question of Power. Heinemann, 1974.

Hodgson, Godfrey. The Myth of American Exceptionalism. Yale UP, 2009.

Hughes, David. "Unmaking an Exception: A Critical Genealogy of US Exceptionalism." Review of International Studies, vol. 41, no. 3, July 2015, pp. 527-51.

Huntington, Samuel P. Who Are We? Challenges to America's National Identity. Simon and Schuster, 2004.

Huysmans, Jef. "The Jargon of Exception-On Schmitt, Agamben and the Absence of Political Society." International Political Sociology, vol. 2, no. 2, 2008, pp. 165-83.

Ignatieff, Michael, editor. American Exceptionalism and Human Rights. Princeton UP, 2005.

Jean-Charles, Régine Michelle. “The Myth of Diaspora Exceptionalism: Wyclef Jean Performs 'Jaspora.”' American Quarterly, vol. 66, no. 3, Sept. 2014, pp. 835-52.

Kammen, Michael. "The Problem of American Exceptionalism: A Reconsideration.” American Quarterly, vol. 45, no. 1, Mar. 1993, pp. 1-43.

Kaplan, Amy. "The Tenacious Grasp of American Exceptionalism." Comparative American Studies: An International Journal, vol. 2, no. 2, 2004, pp. 153-59.

Kaplan, Amy, and Donald E. Pease, editors. Cultures of United States Imperialism. Duke UP, 1993.

Kirby, Vicki. "Human Exceptionalism on the Line." SubStance, vol. 43 , no. 2 , 2014, pp. 50-67.

Koh, Harold Hongju. "On American Exceptionalism." Stanford Law Review, vol. 55, no. 5, May 2003, pp. 1479-527.

Lachman, Kathryn. "The Allure of Counterpoint: History and Reconciliation in the Writing of Edward Said and Assia Djebar." Research in African Literatures, vol. 41, no. 4, winter 2010, pp. 162-86.

Lipset, Seymour Martin. American Exceptionalism: A Double-Edged Sword. W. W. Norton, 1996.
Lowe, Lisa. The Intimacies of Four Continents. Duke UP, 2015.

Luft, Rachel E. "Beyond Disaster Exceptionalism: Social Movement Developments in New Orleans after Hurricane Katrina." American Quarterly, vol. 61, no. 3, Sept. 2009, pp. 499-527.

Mackey, Nathaniel. “And All the Birds Sing Bass.” Introduction. Discrepant Engagement: Dissonance, Cross-Culturality, and Experimental Writing, Cambridge UP, 1993, pp. 1-21.

Madsen, Deborah L. American Exceptionalism. U of Mississippi P, 1998.

McDougall, Walter A. Promised Land, Crusader State: The American Encounter with the World since 1776. Houghton Mifflin, 1997.

Moten, Fred. "There Is No Racism Intended." The Universal Machine, Duke UP, 2018, pp. 1-64.

Nagle, John Copeland. "Climate Exceptionalism.” Environmental Law, vol. 40, no. 1, winter 2010, pp. 53-88.

Oakley, Francis. "The Humanities in Liberal Arts Colleges: Another Instance of Collegiate Exceptionalism?” Daedalus, vol. 138, no. 1, winter 2009, pp. 35-51.

Pease, Donald E. The New American Exceptionalism. U of Minnesota P, 2009.

. "Re-thinking 'American Studies after US Exceptionalism." American Literary History, vol. 21, no. 1, spring 2009, pp. 19-27.

Ramrattan, Lall B., and Michael Szenberg. "American Exceptionalism: An Appraisal-Political, Economic, Qualitative, and Quantitative." The American Economist, vol. 62, no. 2, 2017, pp. 222-46.

Restad, Hilde Eliassen. "Old Paradigms in History Die Hard in Political Science: US Foreign Policy and American Exceptionalism." American Political Thought, vol. 1, spring 2012, pp. 53-76.

Rodgers, Daniel T. “American Exceptionalism Revisited.” Raritan, vol. 24 , no. 2 , fall 2004 , pp. 21-47.

Sachs, Jeffrey D. A New Foreign Policy: Beyond American Exceptionalism. Columbia UP, 2018.

Said, Edward. Culture and Imperialism. Vintage, 1994.

-. Preface. Orientalism. 1978. Anniversary ed., Penguin, 2003, pp. xi-xxiii.

Schmitt, Carl. Political Theology: Four Chapters on the Concept of Sovereignty. Translated by George Schwab, U of Chicago P, 1985.

Shafer, Byron, editor. Is America Different? A New Look at American Exceptionalism. Oxford UP, 1991.

Shih, Shu-Mei. "World Studies and Relational Comparison." PMLA, vol. 130, no. 2, Mar. 2015, pp. 430-38.

Singh, Nikhil Pal. Black Is a Country: Race and the Unfinished Struggle for Democracy. Harvard UP, 2004.

Spanos, William V. "American Exceptionalism in the Post-9/11 Era.” Symplokē, vol. 21, nos. 1-2, 2013, pp. 291-324.

Stokes, Jenna K. "The Indecent Internet: Resisting Unwarranted Internet Exceptionalism in Combating Revenge Porn." Berkeley Technology Law Journal, vol. 29, 2014, pp. 929-52.

Stoler, Ann Laura. "Imperial Formations and the Opacities of Rule." Lessons of Empire: Imperial Histories and American Power, edited by Craig Calhoun et al., New Press, 2006, pp. 48-60. 
Torpey, John. "The End of the World as We Know It? American Exceptionalism in an Age of Disruption." Sociological Forum, vol. 32, no. 4, Dec. 2017, pp. 701-25.

Tyrrell, Ian. American Exceptionalism: A New History of an Old Idea. U of Chicago P, 2021.

"American Exceptionalism in an Age of International History.” The American Historical Review, vol. 96, no. 4, Oct. 1991, pp. 1031-55.

United States, Supreme Court. Downes v. Bidwell. United States Reports, vol. 182, 1901, pp. 244-391. Library of Congress, tile loc.gov/storage-services/service/ll/usrep/usrep182/usrep182244/ usrep182244.pdf. Accessed 14 Jan. 2022.

Walt, Stephen M. "The Myth of American Exceptionalism." Foreign Policy, no. 189, Nov. 2011, pp. 72-75.

Whyte, Jessica. "'I Would Prefer Not To': Giorgio Agamben, Bartleby and the Potentiality of the Law." Law and Critique, vol. 20, no. 3, Nov. 2009, pp. 309-24.

Wilson, George M. "Edward Said on Contrapuntal Reading." Philosophy and Literature, vol. 18, no. 2, Oct. 1994, pp. 265-73. 